\title{
СТАНОВЛЕНИЕ ОТЕЧЕСТВЕННОГО ШКОЛЬНОГО ЭКОЛОГИЧЕСКОГО ОБРАЗОВАНИЯ В ХХ В.
}

\section{THE FORMATION OF NATIONAL SCHOOL ENVIRONMENTAL EDUCATION IN THE XX CENTURY}

\section{Avetisyan}

Summary: Ecology as a school subject has recently acquired a new meaning, instilling a moral, respectful attitude among students to the environment. As an independent academic discipline, "Ecology" has come a long way in its formation. The article analyzes the main historical stages of the formation of ecology in the national school system of the XX century.

Keywords: ecology, history of education, soviet school system, environmental education, school.

\section{Введение}

И стория становления российского экологического образования имеет давние традиции. На протяжении XX столетия школьная система не раз претерпевала преобразования: изменялись подходы, методы, способы изучения тех или иных дисциплин. Одни дисциплины исчезали, иные впервые вводились в учебный процесс. Экология, как самостоятельная учебная дисциплина, первоначально была растворена в других предметах (в естественной истории, естествознании, а позднее в биологии). Лишь к концу столетия стали появляться первые школьные учебники по экологии.

Условно период становления экологического школьного образования заявленного периода можно разделить на дореволюционный, советский и постсоветский периоды. Для получения полноценной картины развития экологического образования каждый из периодов следует рассматривать отдельно.

\section{Экологическое образование на закате Российской империи}

Сведения экологического содержания в образовательной системе Российской империи неразрывно были связаны с общим курсом изучения естествознания. В начале XX в. проблема приобщения юного поколения к знаниям о взаимодействии живых организмов в природе нашла отражение в трудах Д.Н. Кайгородова, В.В. Половцова и др. Каждый из ученых внес свой вклад в развитие экологического образования.
Аветисян Владимир Рудольфович

к.и.н., дочент, ФГБОУ ВО «Самарский государственный сочиально-педагогический университет» vladimir.avetisyan26@mail.ru

Аннотация: Экология как школьный предмет в последнее время приобретает новое значение, прививая у учащихся нравственное, уважительное отношение к окружающей среде. Как самостоятельная учебная дисциплина «Экология» прошла долгий путь В своем становлении. В настоящей статье проведен анализ основных исторических этапов становления экологии в отечественной школьной системе XX столетия.

Ключевые слова: экология, история образования, советская школьная система, экологическое образование, школа.

В 1902 г. русский лесовод, педагог и популяризатор естествознания Дмитрий Никифорович Кайгородов разработал новую школьную программу по природоведению. Ученый являлся сторонником «экскурсионного» метода обучения. Таким образом, по его мнению, можно было привить у учеников интерес и любовь к природе [16; С.13]. Д.Н. Кайгородов предлагал изучать живой мир по природным сообществам, которые условно назвал «общежитиями». По некоторым данным, он заимствовал эту идею у немецкого учителя Фридриха Юнге, который в 1885 г. опубликовал свой труд «Деревенский пруд как общежитие». О значимости педагогической деятельности Д.Н. Кайгородова говорит и тот факт, что с 1889-го по 1891 гг. он преподавал естественную историю великому князю Михаилу Александровичу Романову [16; С.14].

Ученый стремился привлечь к экологической проблематике людей разных возрастов. В иллюстрированных детских журналах «Игрушечка. Журнал для маленьких детей», «Родник», «Семейные вечера» он публиковал статьи и сказки естественно-исторического содержания. В 1902 г. Д.Н. Кайгородов опубликовал работу «Из родной природы. Хрестоматия для чтения в народной школе и семье» [5], куда вошли сведения о животном и растительном мире России.

Многие из современников Д.Н. Кайгородова критиковали его программу, называя ее неудачной в методологическом отношении. В 1904 г. она была заменена на другую, разработанную педагогом и основоположником методики преподавания естествознания А.Я. Гердом еще в XIX в. Ученый был сторонником замены «описатель- 
ного» естествознания «объясняющим», основанного на большом количестве самостоятельных опытов, наблюдений на экскурсиях и в классе [13; С.49]. В то же время, как отмечают И.Н. Пономарева и В.П. Соломин, благодаря этой критике, стали появляться идеи по обогащению школьного естествознания материалами эволюционного учения [11].

Развитию экологического образования способствовали также школьные биологические станции, первая из которых была открыта в 1910 г. в Павловске. Она была ориентирована на детей местных дачников, которые совершали экскурсионные походы и самостоятельные наблюдения за животными в аквариумах и террариумах [13; C.51].

Большую роль в развитии школьного экологического образования сыграла педагогическая деятельность профессора Петербургского университета Валериана Викторовича Половцова. В 1907 г. он основал Общество распространения естественнонаучного образования (OРEO) и журнал по методике естествознания «Природа в школе». Как отмечал Б.Е. Райков, ученый рекомендовал строить преподавание на самостоятельных практических занятиях и экскурсиях [12].

В истории методики естествознания В.В. Половцов известен также как пропагандист внедрения экологических знаний. Работа ученого «Основы общей методики естествознания», изданная в 1907 г., была направлена на обоснование необходимости включения экологических материалов в курс школьного образования. Он являлся сторонником биологического метода обучения - изучения строения живых организмов на основе связи с окружающей средой. Отметим, что сами термины «экология», «экологическая» в его трудах не используются, а заменены на «биология», «биологическая». Возможно, это было связано с невостребованностью «экологических» терминов в тот период или отнесением экологии к «биологии в узком смысле слова».

\section{Школьное экологическое образование в СССР}

Экологическое школьное образование в СССР прошло ряд преобразований и реорганизаций. В зависимости от общей политической ситуации в стране экология то приобретала особую значимость, то практически не преподавалась в школе.

Согласно «Положению о единой трудовой школе...» [8] от 16 октября 1918 г. вводилась единая система совместного и бесплатного общего образования с двумя ступенями (5 и 4 года обучения соответственно). Стали готовиться новые школьные программы, вводилось трудовое обучение. Вместе с тем в начале 1920-х гг. с дореволюционной структурой школьного образования было фактически покончено. Согласно установкам программ Государственного ученого совета, школа с ее классами, уроками, на которых учащимся сообщались готовые знания, стала считаться устаревшей. Учащиеся должны были самостоятельно добывать знания на экскурсиях, в общественно полезной работе, а учитель - предоставлять ученикам полную самостоятельность и свободу деятельности.

Деятельность Общества распространителей естественнонаучного образования первоначально не была упразднена советскими властями. В 1918 г. его возглавил методист-биолог, доктор педагогических наук Борис Евгеньевич Райков. Общество функционировало до 1929 г. $[1 ;$ C.131]

Период 1920-1925 гг. объявлялся временем ликвидации неграмотности. К концу 1920-х гг. школьное образование стало постепенно выходить из глубокого кризиса (общее количество учащихся выросло на 43\%). В 1932 г., после принятия советским правительством соответствующих постановлений в СССР была восстановлена предметная система обучения, появились единые школьные программы, рассчитанные на использование в течение нескольких учебных лет. Экологические сведения вобрал в себя предмет «Биология», однако объем этих сведений оставался ограниченным.

Отдельные вопросы преподавания экологии в школе освещались в учебно-методической литературе этого периода и в основном касались описания животных и растений. Подтверждение этому можно найти в пособии для высших педагогических учебных заведений и преподавателей средней школы «Методика зоологии» [7] под редакцией М.М. Беляева и Н.Г. Кременецкого, изданном в 1936 г. Кроме того, педагог Б.Е. Райков выступал за наличие отдельных биологических дисциплин в школьной образовательной системе. Ввиду того, что подобное мнение шло в разрез общегосударственной политики страны в области образования, Б.Е. Райков был снят с занимаемой должности и отправлен в отставку [1; С.132].

Стоит отметить, что в 1950-е гг. в советской школе начался процесс политехнизации образования. На уроках биологии больше внимания стало уделяться сущности процессов и явлений в живой природе и их взаимодействию с медициной, промышленностью или сельским хозяйством. Для этих целей была переработана учебная и вспомогательная литература.

В начале 1960-х гг. с изменением политического курса в стране и отходом от идей Т.Д. Лысенко серьезные преобразования произошли и в школьной образовательной системе. О значимости природоохранного просвещения говорил педагог и методист Николай Александрович Рыков. В 1961 г. он опубликовал брошюру «Охрана при- 
роды и школа» [9], куда включил рекомендации по организации школьного общества охраны природы, которое, по мнению педагога, должно было способствовать пропаганде идеи охраны природы в ходе обучения биологии [1; С.136].

В свою очередь о росте заинтересованности государственных образовательных структур в формировании у учащихся школ нравственного отношения к природе свидетельствует принятый в 1960 г. Закон «Об охране природы в РСФСР» [2], который предусматривал формирование двухступенчатой системы преподавания основ охраны природы в учебных заведениях. С этой целью в школьные программы и учебники по географии, химии и биологии включались основы охраны природы. В начальной школе появился самостоятельный предмет природоведение [10; С.479].

Согласно новой программе по биологии, разработанной под руководством профессора Юрия Ивановича Полянского, экологическим проблемам стали уделять больше внимания. В пояснительной записке к программе было отмечено «усиление экологического материала». Учителя биологии испытывали трудности, так как до 1975 г. в программе подготовки педагогических кадров дисциплины «Экология» не было. Помощь учителям в вопросах преподавания экологических знаний оказывал журнал «Биология в школе», на страницах которого публиковались методические рекомендации.

В 1970-х гг. в СССР были заложены основы теории экологического образования (разработаны цели и задачи экологии в обучении и воспитании школьников). Стали вводиться факультативные курсы экологического содержания.

Начиная с 1980-х гг. в стране идеи экологического образования получили обобщение в концепции его непрерывности от дошкольного до послевузовского уровня. Подобная система позволила разработать отдельные задачи для каждой образовательной ступени.

На рубеже 1980-1990-х гг. экология как наука приобрела особую актуальность. Она стала рассматриваться как интегративная область знаний, включающая не только биологию, но и другие науки.

\section{Российское школьное экологическое образование в 1990-х гт.}

В начале 1990-х гг. в России стали открываться образовательные учреждения нового типа - гимназии, лицеи, школы с углубленным изучением отдельных предметов, в том числе биологии. Содержание биоэкологического образования стало видоизменяться. Учебная литература начала издаваться под разными авторскими линиями
[14; С.339]. Экологическое образование в России приобрело одно из приоритетных направлений работы отечественной школы. В учебных программах появились специальные экологические темы. Параллельно с экологизацией существующих учебных дисциплин, были введены специализированные экологические предметы федерального и регионального уровней.

Преобразования в области школьного экологического образования нашли подкрепление в нормативно-правовых документах, принятых в начале 1990-х гг. Первоначально стоит обратиться к закону «Об образовании» от 1992 г., который в качестве одного из принципов государственной политики в области образования предписывал «воспитание... любви к окружающей природе» [3]. Схожее постановление находим в опубликованном 4 февраля 1994 г. Указе Президента №236 «О государственной стратегии Российской Федерации по охране окружающей среды и обеспечению устойчивого развития», второй раздел которого предписывал «в целях создания условий, позволяющих реализовать конституционное право граждан на жизнь в благоприятной окружающей среде... [предусмотреть] экологическое воспитание и образование населения» [15]. Годом ранее с целью сохранения единства образовательного пространства страны был создан Проект государственного образовательного стандарта общего образования.

В 1993 г. группа ученых под руководством советского и российского эколога Н.М. Черновой разработала «Временный государственный образовательный стандарт школьного экологического образования». Основная его идея заключалась в осуществлении экологического образования на всех этапах системы общего школьного образования. Как результат, уже в 1994 г. в учебный план старших классов была введена самостоятельная дисциплина «Экология» [4; С.94].

21 апреля 1994 г. во исполнение Закона РФ «Об охране окружающей природной среды» в части обеспечения гласности в работе государственной природоохранной системы, прав граждан и общественных организаций на необходимую и достоверную информацию о состоянии окружающей среды и мерах по ее охране было учреждено Российское экологическое федеральное информационное агентство. Деятельность агентства во многом также оказывала содействие в формировании уважительного отношения к природе среди подрастающего поколения [6; С.969].

Стала издаваться школьная литература по экологии. Так в 1995 г. в свет вышли учебники «Экология» авторов Е.А. Криксунова, В.В. Пасечника и А.П. Сидорина и «Экология России» под редакцией Б.М. Миркина и Л.Г. Наумовой. В 1996 г. под редакцией С.В. Алексеева был опубликован «Практикум по экологии». К концу столетия 
появились подобные учебные пособия для начальных классов.

Несмотря на подъем внимания к экологическому школьному образованию в начале и середине 1990-х гг., уже к концу десятилетия данная тенденция ослабевает, и как следствие, в 1998 г. предмет «Экология» изымается из учебного плана старших классов. Связано это было, прежде всего, с реформированием государственных структур, занимающихся природоохранными вопросами и способствовавших развитию экологического образования в стране. Например, созданный в 1988 г. Государственный Комитет по охране природы СССР в 1991 г. был преобразован в Министерство экологии и природопользования РФ. На его базе в 1992 г. было учреждено Министерство охраны окружающей среды и природных ресурсов РФ, разделенное в 1996 г. на Государственный Комитет РФ по охране окружающей среды и Министер- ство природных ресурсов РФ [4; С.94].

\section{Зак^ючение}

Таким образом, можно констатировать, что экологическое школьное образование в России на протяжении XX столетия прошло весьма сложный путь от растворенной в других учебных дисциплинах знаний, до самостоятельного предмета. Анализ историографии по заявленной проблеме продемонстрировал озабоченность выдающихся российских педагогов и методистов по внедрению и развитию экологических знаний в школе на протяжении многих десятилетий. Исторический анализ заявленной проблематики продемонстрировал значимость внедрения полноценного школьного экологического образования, как одного из факторов формирования гражданственности, нравственного и уважительного отношения к природе.

\section{ЛИТЕРАТУРА}

1. Андреева Н.Д., Малиновская Н.В., Соломин В.П. История становления и развития методики преподавания биологии в России: учебное пособие. - СПб.: Изд-во РГПУ им. А.И. Герцена, 2012. - 172 с.

2. Закон РСФСР «0б охране природы в РСФСР; Постановление Президиума Верховного Совета РСФСР: о ходе выполнения закона РСФСР от 27 октября 1960 года «0б охране природы В РСФСР». В президиуме центрального совета Всероссийского общества охраны природы. - Москва: [6. и.], 1966. - 69 с.

3. Закон РФ от 10.07.1992 N 3266-1 (ред. от 12.11.2012) «06 образовании»// http://www.consultant.ru/document/cons_doc_LAW_1888/432b6e2b41f2241f44 bf631a207bef41b358b12d/ (дата обращения: 02.09.2021).

4. Иванова Л.Ю. Экологическое образование и образование для устойчивого развития в Российской школе: настоящее и будущее // Вестник института социологии. - 2017. - №4. - Т.8. - С.91-112.

5. Кайгородов Д.Н. Из родной природы. Хрестоматия для чтения в народной школе и семье. - СПб.: Издание А.С. Суворина, 1904. - 263 с

6. Маркова Е.Н., Шавырина 0.Б. Основные этапы развития экологического образования в России // Сборник материалов и докладов VI Всероссийской научно-практической конференции по экологическому образованию. Под общей редакцией В.А. Грачева. - 2020. - С.965-970.

7. Методика зоологии: Пособие для высших педагогических учебных заведений и преподавании средней школы: Утв. Наркомпросом РСФСР / М.М. Беляев, Н.Г. Кременецкий. - Москва: Учпедгиз, 1936. - 560 с.

8. О Единой Трудовой Школе Российской Социалистической Федеративной Советской Республики // Собрание узаконений и распоряжений правительства за 1917 - 1918 гг. Управление делами Совнаркома СССР М. 1942, С.1026-1030.

9. Охрана природы и школа / Н.А. Рыков, д-р пед. наук; Всерос. о-во охраны природы. Ленингр. отд-ние. - Ленинград: Лениздат, 1961. - 56 с.

10. Пинаева Д.А. Популяризация экологических знаний в СССР в 1960-1980-е гг.// В сборнике: Хартия Земли - практический инструмент решения фундаментальных проблем устойчивого развития. Сборник материалов международной научно-практической конференции, посвященной 15-летию реализации принципов Хартии Земли в Республике Татарстан. - 2016. - С.478-483.

11. Пономарева И.Н., Соломин В.П. Экологическое образование в российской школе: История. Теория. Методика: Учебное пособие / под ред. В.П. Соломина. - СПб.: Изд-во РГПУ им. А.И. Герцена. -415 с.

12. Райков Б.Е. Валериан Викторович Половцов, его жизнь и труды. - Москва-Ленинград: Изд-во Акад. Наук СССР, 1956. - 330 с.

13. Самокиш А.В. Школьные и инструкторские биологические станции в Петрограде-Ленинграде // Историко-биологические исследования, 2014, Т.6, №1. C. $48-71$

14. Семенов А.А., Сайто Х. Становление и развитие школьного биологического образования в современной России // Самарский научный вестник. - 2018, № 3(24). - - (.339-343.

15. Указ Президента РФ от 04.02.94 N 236 «0 государственной стратегии Российской Федерации по охране окружающей среды и обеспечению устойчивого развития» // https://normativ.kontur.ru/document?moduleld=1\&documentld=3897 (дата обращения: 29.08.2021).

16. Ученые - фондообразователи Санкт-Петербургского филиала Архива Российской академии наук: краткий биографический справочник / науч. ред. и сост. Е.Ю. Басаргина, И.В. Тункина; Минобрнауки России, СПбФ АРАН. - СПб.: «Реноме», 2020. - 168 с. 